\title{
CHEMICAL CONSTITUENTS OF Senniella spongiosa (F. Muell.) Aellen
}

(Received: 9.8.2009)

\author{
By \\ F.A. Ahmed and Sh. Sh. Emam \\ Medicinal and Aromatic Plants Department, Desert Research Center, El-Matareya, Cairo, Egypt.
}

\begin{abstract}
This study aimed to investigate the chemical constituents of the perennial Senniella spongiosa stems and leaves under influences of Alexandria - Mersa Mattruh road environmental conditions at 30 $\mathrm{km}$ from Alexandria during summer and winter seasons of 2006-2007. Phytochemical screening of the stems and leaves of $S$. spongiosa revealed some differences in the chemical constituents. Chlorophyll a, $\mathrm{b}$ and total carotenoids were high during winter in the leaves compared with the stems in the summer. The moisture content reached its maximum value during winter for plant stems and its minimum value during summer for plant leaves, while the organic matter reached its maximum value during summer for plant stems, and its minimum value during winter for plant leaves. In addition, the total ash content reached its maximum value during summer for plant leaves and its minimum value during winter for plant stems. The percentages of crude fibres and total nitrogen reached their maximum values in winter, for plant leaves and stems. Also, the percentages of total carbohydrates reached their maximum value for plant leaves in winter and minimum value during summer for plant stems. On the other hand, the percentages of total phenolics, alkaloids, tannins and flavonoids reached their maximum values during the summer season for plant leaves and stems, and the lowest values were detected during winter for plant leaves and stems. The phenolic compounds were most abundant in summer. Meanwhile the percentage of total oxalates reached its maximum value during winter season for plant leaves and stems. Moreover, the stems and leaves possessed higher contents of $\mathrm{Fe}$ and $\mathrm{Zn}$ during the summer season. Proline was accumulated in plant stems and leaves in winter season. while, high glycine betaine and choline hydrochloride contents were found in plant leaves during summer. From these data, it is suggested that under stress $S$. spongiosa plants tended to accumulate secondary metabolic products, which may be a part of a suite of adaptation to unfavourable conditions.
\end{abstract}

Keywords: Chenopodiaceae, photosynthetic pigments, phytochemical constituents, secondary metabolites, Senniella spongiosa.

\section{INTRODUCTION}

Medicinal plants are of great importance to the health of individuals and communities. Their medicinal value lies in some chemical substances that produce a definite physiological action on the human body. The most important of these bioactive constituents of plants are alkaloids, tannins, flavonoids, phenolic compounds, glycosides, essential oils, fatty oils, resins, mucilage, gums and others. These are potent bioactive compounds found in medicinal plant parts that can be used for therapeutic purposes or which are precursors for the synthesis of useful drugs (Edeoga et al., 2005).

Approximately 1300 species of chenopods (family: Chenopodiaceae) worldwide range from annual herbs to trees. Many species of chenopods are allocated among $\mathrm{C} 4$ photosynthesis plants. The flowers are tiny and inconspicuous, but some species bear showy masses of fruits. Chenopods are common in deserts and especially in saline or alkaline soils. The genus Senniella is represented by different species distinguished by various morphological, biological cycles and ecological adaptations (Houerou et al., 1995). Senniella shrubs have adaptations enabling them to tolerate the adverse effects of salts internally, or excrete salt from cells and tissues (McKell, 1994).

Many species of Senniella are valued as livestock forage when herbage availability is low especially in arid environments and salt-affected area (Houerou et al., 1995) because they have high contents of crude protein, vitamins (A, C and D) and minerals such as chromium (Shani et al., 1972 and Mckell, 1989).

The chromatographic investigation of the phenolic acids content of $S$. spongiosa stems and leaves revealed that the leaves contained phenolic acids, ferulic, chlorogenic, caffeic and gallic acids. while the plant stems contained the phenolic acids, 
2, 3-dihydroxy benzoic acid ( $O$-protocatechuic acid), ferulic, chlorogenic and $p$ - hydroxy benzoic acid (Emam and Ahmed, 2006). El-Lamey (2005) reported that the phenolic compounds increased with increasing stress; thus a high concentration of phenolic compounds was detected in summer than in winter. Plant derived flavonoids possess antitumor properties, thus they act as chemotherapeutic agents for cancer. Apigenin inhibits the expression of vascular endothelial growth factor in human ovarian cancer cells (Ray Sahelian, 2005). Several types of tannins show anticarcinogenic and antimutagenic effects (Bravo, 1998) have antioxidant protective effects on DNA and gene expression, and inhibit the initiation, promotion and progression of tumors (Chung et al., 1998).

The objective of this study was to determine the proximate analysis and main chemical constituents of leaves and stems of Senniella spongiosa during summer and winter seasons.

\section{MATERIALS AND METHODS \\ 2.1. Collection of plant materials}

Senniella spongiosa (F. Muell.) Aellen variety holocarpa (F. Muell.) was collected from (Alexandria-Mersa Mattruh road) at $30 \mathrm{~km}$ from Alexandria during summer and winter seasons of 2006-2007. The collected plant materials were washed with tap water followed by distilled water.

\subsection{Photosynthetic pigments}

Photosynthetic pigments in fresh leaves and stems were determined quantitatively according to the method of Metzner et al. (1965).

\subsection{Extraction of plant materials}

The leaves and stems of the plants were airdried at room temperature for 2 weeks, after which they were ground to a uniform powder. The ethanol extracts were prepared by soaking $100 \mathrm{~g}$ of each of the dry powdered plant part materials in ethanol at room temperature for $48 \mathrm{hr}$. The extracts were filtered through a Whatmann filter paper No. 42 and then through cotton wool. The extracts were concentrated using a rotary evaporator at $40^{\circ} \mathrm{C}$.

\subsection{Phytochemical screening}

The qualitative determination of flavonoids, saponins, tannins, alkaloids and steroids in ethanolic extracts of stems and leaves were performed according to the method of Woo et al. (1977), Sofowara (1993) Mojab et al. (2003), Edeoga et al. (2005) and Edeoga et al. (2006).

\subsection{Pharmacopeial constants}

The organic matter, moisture content, crude fibre and total ash contents were determined as described by Alabi et al. (2005). Crude ash was determined according to Petterson et al. (1999).

2.6. Quantitative determination of the chemical constituents

\subsubsection{Determination of total lipids and crude protein}

Total lipids and crude protein of defatted plant stems and leaves samples were determined according to AOAC (2000).

\subsubsection{Determination of total carbohydrates}

Total carbohydrates were determined by the method of Chaplin and Kennedy (1994).

\subsubsection{Colorimetric determination of the total phenolic compounds}

Total phenolics were colorimetricall determined according to the method of Pulido et al. (2000) as follows: a test sample $(0.5 \mathrm{ml})$ was mixed with $1 \mathrm{ml}$ of Folin-Ciocalteu reagent and swirled. After $3 \mathrm{~min}, 10 \mathrm{ml}$ of sodium carbonate solution (75 g/l) were added and mixed. Additional distilled water was mixed thoroughly by inverting the tubes several times. After $1 \mathrm{~h}$, the absorbance at $750 \mathrm{~nm}$ was recorded using a spectrophometer. The results were expressed as gallic acid equivalents.

\subsubsection{Identification and determination of phenolic compounds in plant stems and leaves extracts by HPLC \\ Identification of individual phenolic} constituents of the plant stems and leaves extracts were performed on a Hewlett-Packard HPLC apparatus (Model 1100), using a hypersil $\mathrm{C}_{18}$ reversed-phase column $(250 \times 4.6 \mathrm{~mm})$ with $5 \mu \mathrm{m}$ particle size. Phenolic compounds of each sample were identified by comparing their relative retention times with those of the standard mixture chromatogram. The concentration of each compound was calculated on the basis of peak area measurements, and converted to $\mu \mathrm{g}$ phenolic $\mathrm{g}^{-1}$ dry weight. This method was reported by BenHammouda et al .(1995).

\subsubsection{Flavonoid and alkaloid determination}

Flavonoid and alkaloid contents in of ethanolic extracts of plant stems and leaves were determined according to the method of Karaway and Aboutabl (1982) and Balbaa (1986), respectively.

\subsubsection{Tannin determination}

Tannins of plant stems and leaves were determined in aqueous extract according to the method of Van-Burden and Robinson (1981).

\subsubsection{Determination of total oxalate}

Total oxalate of plant stems and leaves was determined in acidic aqueous extract according to the method of Hodgkinson (1971).

\subsection{Elements measurements}


Sodium and potassium were determined in the digested samples of the leaves and stems using a flame photometer according to Allen (1989). Phosphorus content in the digested samples was determined colorimetrically by the molybdic acid method as described by Humphries (1956). The contents of $\mathrm{Ca}^{++}$were determined using Unicam 929 atomic absorption spectrophotometer.

\subsection{Proline content and quaternary bases}

Proline content of leaves and stems of $S$. spongiosa was determined according to the method described by Ait Baraka and Audran (1997). Glycine betaine and choline betaine were measured in stems and leaves tissue extracts as described by Lever et al. (1992).

\section{RESULTS AND DISCUSSION}

\subsection{Phytochemical screening}

Phytochemical screening of the stems and leaves of $S$. spongiosa revealed some differences in the chemical constituents (Table 1). The obtained results showed that both plant parts were rich in flavonoids, alkaloids and tannins. The presence of these active constituents in the investigated plant account for its usefulness as a medicinal plant. These results are in agreement with those obtained by Edeoga et al. (2006).

Table (1): Phytochemical screening of Senniella spongiosa.

\begin{tabular}{|c|c|c|}
\hline Item & Stems & Leaves \\
\hline Flavonoids & +ve & ++ve \\
\hline Saponins & -ve & -ve \\
\hline Tannins & +ve & ++ve \\
\hline Alkaloids & ++ve & +ve \\
\hline Steriods & ++ve & +ve \\
\hline
\end{tabular}

Where: ++ve $=$ Highly positive results

$+\mathrm{ve}=$ Moderate positive results $-\mathrm{ve}=$ Negative results

\subsection{Photosynthetic pigments}

Chlorophyll (a and b ) and carotenoid contents in the fresh leaves and stems of the S. spongiosa are presented in Table (2). The results revealed that chlorophyll $\mathrm{a}$ and $\mathrm{b}$ and carotenoids were higher during winter than that in summer and in leaves than in stems. The largest amount of 5.12, 2.00 and $0.49 \mu \mathrm{g} / \mathrm{g}$ fresh weight, respectively were recorded during winter in plant leaves. Morsy (2002) reported that crynohalophytes attained higher concentrations of photosynthetic pigments under salt stress in their extremely arid habitat. Elabsy (2006) suggested that the increase in carotenoids may be considered as one of the adaptive responses which can delay senescence and maintain the survival of stressed plants through protection against oxidative stress. Morsy (2008) reported that the photosynthetic pigments, carbohydrates and crude protein of Atriplex farinosa of family Chenopodiaceae attained their high levels under high saline conditions.

Table (2): Photosynthetic pigments of Senniella spongiosa.

\begin{tabular}{|c|c|c|c|c|}
\hline \multirow{2}{*}{$\begin{array}{l}\text { Pigment } \\
\text { content } \\
\left(\boldsymbol{\mu g}^{-1} \mathbf{g} \text { f.wt. }\right)\end{array}$} & \multicolumn{2}{|c|}{ Stems } & \multicolumn{2}{|c|}{ Leaves } \\
\hline & Summer & Winter & Summer & Winter \\
\hline Chlorophyll a & 2.64 & 3.02 & 4.01 & 5.12 \\
\hline Chlorophyll b & 0.67 & 0.88 & 1.80 & 2.00 \\
\hline Carotenoids & 0.05 & 0.08 & 0.36 & 0.49 \\
\hline
\end{tabular}

\subsection{Pharmacopeial constants}

\subsubsection{Moisture content}

Data presented in Table (3) indicate that the moisture content of $S$. spongiosa reached its maximum value of $64.50 \%$ during winter in plant stems and its minimum value of $19.47 \%$ during summer in plant leaves. The decrease of water content in summer may be due to the increase in the rate of transpiration of the plant and evaporation accompanied with increasing of wind velocity and temperature (Jain, 1997).

\subsubsection{Organic matter}

Table (3) shows the organic matter content of $S$. spongiosa plant. The results showed that the organic matter reached its maximum value of $63.57 \%$ during summer for plant stems, while its minimum values of $38.56 \%$ was recorded during winter for plant leaves.

\subsubsection{Ash content}

Data presented in Table (3) indicate that the total ash content of $S$. spongiosa reached its maximum value of $27.58 \%$ during summer in plant leaves and its minimum value of $10.49 \%$ during winter in plant stems. From the obtained data, it was observed that the total ash percentages tended to increase in the dry season (summer) but declined in the rainy season (winter). This may be attributed to the increase in total ion accumulation because of increasing soil moisture stress during summer. This agrees with the findings of Larcher (1995). Al-Owaimer et al. (2008) reported that ash contents were 16.61 and $16.42 \%$ for Atriplex halimus and A. lecucoclada, respectively. Meanwhile Rizk (1986) reported that Schanginia aegyptiaca, of family Chenopodiaceae contained had a very high ash content $(39.82 \%)$. This reflects the particular origin of the plant which grows on salinized soil. The analysis of the ash indicated that iron is present in high percentage $(10.08 \%)$ followed by manganese $(6.98 \%)$ and zinc $(4.54 \%)$ while coppercontent was $0.07 \%$.

\subsubsection{Crude fibres}

Crude fibres of $S$. spongiosa reached their maximum values of 17.58 and $13.25 \%$ in winter, 
while their minimum values of 15.70 and $11.49 \%$ were recorded during summer for plant leaves and stems, respectively (Table 3 ). The results of AlOwaimer et al. (2008) showed that crude fibre of Atriplex halimus and A. lecucoclada ranged from $29.09 \%$ to $32.47 \%$. The low values of crude protein and high values of crude fibre may be due to the lower percentage of leaves then stems in the two types of Atriplex used.

\subsection{Chemical composition of stems and leaves of $S$. spongiosa plant}

\subsubsection{Total crude protein content}

Data presented in Table (3) indicate that the percentages of total nitrogen reached their maximum values of (1.23 and $4.56 \%)$ during winter and their minimum values of $(0.80$ and $3.72 \%$ ) during summer, for plant stems and leaves, respectively. Total crude protein of $S$. spongiosa reached its maximum value of $28.5 \%$ for plant leaves in winter and its minimum value of $5.00 \%$ for plant stems in summer. In general, the amount of protein decreased during summer months and increased during winter months. This may be due to the increase in the metabolic rate of plants as a result of high water resources of the soil during winter than that during the dry period. The increase in the soil moisture stress may remarkably increase the assimilation and accumulation of nitrogenous compounds in $S$. spongiosa. Ahmed and Girgis (1979) emphasized the importance of nitrogen intermediates as osmotically active ingredients in plant metabolism and showed that desert plants depend, to a large extent, on the accumulation of organic intermediates in building up their osmotic pressure. Rizk (1986) reported that Schanginia aegyptiaca of family Chenopodiaceae has been found to contain protein $(10.50 \%)$, moisture $(84.75 \%)$, lipids $(1.64 \%)$, crude fibre $(5.93 \%)$, soluble carbohydrates (22.33\%), mucilage $(2.10 \%)$ and carbohydrates $(17.68 \%)$. Aganga $e t$ al. (2003) reported that Atriplex nummularia contains high concentrations of nitrogen $(\mathrm{N})$ in winter as compared to summer when it has high concentrations of sodium. Al-Owaimer et al. (2008) reported that similar crude protein values were found in $A$. halimus $(9.6 \%)$ and $A$. lecucoclada $(9.58 \%)$.

\subsubsection{Total lipids}

The total lipid content of $S$. spongiosa reached its maximum value of $5.92 \%$ during winter for plant leaves and its minimum value of $1.51 \%$ during summer for plant stems (Table 3). It is obvious from the obtained data that the total lipid percentages are higher in winter than in summer. This may be due to the increase in the metabolic rate of $S$. spongiosa during winter which leads to an increase in carbohydrate content, which in converted to lipid by oxidation reactions. As a general conclusion from this study, the total ash was higher in summer than in winter, which may be attributed to the lower moisture content and fat was higher in winter, while fibres content, showed seasonal fluctuation in winter and summer because of the response of the plant to different stress conditions in both seasons.

\subsubsection{Total carbohydrate contents}

Results indicated that carbohydrates content varied with each season and in different plant parts. It is clear from Table (3) that the percentages of total carbohydrates reached their maximum value of $9.08 \%$ for plant leaves in winter months, while the minimum value was $2.56 \%$ during summer for plant stem. On the other hand, Abo-Kassem et al. (2002) reported that high salt concentration can result in osmotic adjustment by regulating the accumulation of solutes especially sugars and proteins. Mohamed and Alain (1995) suggested that the accumulation of carbohydrates under salinity stress is due to a reduction in their utilization, either as a source of energy or for the formation of new cells and tissues.

\subsubsection{Total phenolics}

It was observed from Table (3) that, there was a tendency to a gradual decline in total phenolics from summer to winter samples, where the percentage of total phenolics reached its maximum values (1.13 and 1.65) during summer for plant stems and leaves, while its minimum values were recorded in winter (0.69 and 0.87) for plant stems and leaves. A similar pattern of variability in the level of total phenolics was also reported by Ahmed (2004) in Ballota undulata. This declining trend of total phenolics in leaves and stems of S. spongiosa may be due to increased activity of esterase and peroxidase enzymes which are responsible for the oxidation of phenolic compounds in plant tissues.

\subsubsection{Total alkaloids}

It is obvious from Table (3) that the percentages of total alkaloids reached their maximum values of 0.86 and $0.65 \%$ during summer for plant leaves and stems, respectively. Water stress has been shown to increase alkaloid percentage in plants. It has been observed that alkaloid bearing plants are often more potent in dry periods than in wet periods (Gershenzon, 1984). El- Lamey (2005), reported that there was a tendency of the medicinal plants to accumulate alkaloids by stress, where the accumulation of alkaloids was significantly increased in dry seasons.

\subsubsection{Total tannins}


It could be concluded that the highest percentage of tannin $(8.19 \%)$ was detected in plant leaves during summer and the lowest percentage $(5.23 \%)$ was detected in plant stems during winter. It was clear that the leaves contain the highest percentage of tannin. The high percentage of tannins in the different organs under investigation may encourage their probable use in diarrhea, bleeding, piles, as well as in tanning (Ghazanfar, 1994). The accumulation of some phenolic compounds (total phenolics and tannins) under stress can be considered as an adaptive response to conditions under which the functions of these compounds become more important (Gershenzon,1984).
December were 2.9 and 2.0,respectively, while those of tannins were 5.1 and 6.2 ; those of crude fibre were 15.2 and 34.6; and percentages of crude protein were 10.3 and 5.9 , respectively. Oke (1966) reported that large amount of total oxalate and hydrocyanic acid in any tissue lowers the nutritive values. Oxalic acid, a strong chelating agent usually found in plants, forms crystals with cations such as $\mathrm{Ca}$ (Gallher, 1975). These calcium oxalate crystals are insoluble in water, alkali, and organic acids. Emam and Ahmed (2006) reported that oxalic acid was detected in the leaves and stems of S. spongiosa $(5.139$ and $4.154 \mathrm{mg} / 100 \mathrm{~g}$, respectively) using HPLC technique.

Table (3): Pharmacopeaial constants and chemical composition (\%) of stems and leaves of Senniella spongiosa.

\begin{tabular}{|l|c|c|c|c|}
\hline \multirow{2}{*}{\multicolumn{1}{c|}{$\begin{array}{c}\text { Item } \\
(\%)\end{array}$}} & \multicolumn{2}{c|}{ Stems } & \multicolumn{2}{c|}{ Leaves } \\
\cline { 2 - 5 } & Summer & Winter & Summer & Winter \\
\hline Moisture content & 55.10 & 64.50 & 19.47 & 23.23 \\
\hline Organic matter & 63.57 & 52.70 & 44.31 & 38.56 \\
\hline Ash content & 13.25 & 10.49 & 27.58 & 25.70 \\
\hline Crude fiber & 11.49 & 13.25 & 15.70 & 17.58 \\
\hline Total nitrogen & 0.80 & 1.23 & 3.72 & 4.56 \\
\hline Crude protein & 5.00 & 7.69 & 23.25 & 28.50 \\
\hline Lipid content & 1.51 & 3.96 & 1.87 & 5.92 \\
\hline Carbohydrates & 2.56 & 8.20 & 3.12 & 9.08 \\
\hline Total phenolics & 1.13 & 0.69 & 1.65 & 0.87 \\
\hline Total alkaloids & 0.65 & 0.29 & 0.86 & 0.42 \\
\hline Total tannins & 6.83 & 5.23 & 8.19 & 6.47 \\
\hline Total flavonoids & 0.182 & 0.012 & 0.270 & 0.017 \\
\hline Total oxalates & 6.03 & 8.56 & 8.12 & 10.30 \\
\hline
\end{tabular}

\subsubsection{Total flavonoids}

The total flavonoids in the leaves and stems of S. spongiosa were determined spectrophotometrically and calculated as kaempferol. The percentage of total flavonoids reached its maximum values of 0.27 and $0.182 \%$ during summer for plant leaves and stems, respectively. The presence of flavonoids and tannins in the plants is likely to be responsible for the free radical scavenging effects observed. Flavonoids and tannins are phenolic compounds and plant phenolics are a major group of compounds that act as primary antioxidants or free radical scavengers (Polterait, 1997).

\subsubsection{Total oxalates}

Data presented in Table (3) indicate that, the leaves contain higher percentages of oxalates than stems. The percentages of total oxalates reached their maximum values of 10.30 and $8.56 \%$ during winter for plant leaves and stems, respectively. Rizk (1986) reported that the percentages of oxalates in Triplex leucoclada in August and

\subsubsection{Phenolic compounds in the stems and} leaves of $S$. spongiosa using HPLC

The obtained results shown in Table (4) reveal that the concentration of phenolic compounds in $S$. spongiosa increased with stress except for ocoumaric acid and $\rho$-coumaric acid. The concentration of ferulic acid increased from 6.19 $\mu \mathrm{g} / \mathrm{g}$ in winter to $17.24 \mu \mathrm{g} / \mathrm{g}$ in summer whereas chlorogenic acid concentration increased from $7.11 \mu \mathrm{g} / \mathrm{g}$ in winter to $15.21 \mu \mathrm{g} / \mathrm{g}$ in summer. The concentration of phenol increase from $7.34 \mu \mathrm{g} / \mathrm{g}$ in winter to $14.40 \mu \mathrm{g} / \mathrm{g}$ in summer. Quercetin concentration increased from $0.22 \mu \mathrm{g} / \mathrm{g}$ in winter to $0.42 \mu \mathrm{g} / \mathrm{g}$ in summer.

\subsection{Elements measurements}

Table (5) presents the elements composition of stems and leaves of Senniella spongiosa in summer and winter. The data showed that the maximum content of $\mathrm{Fe}$ in plant stems and leaves during summer was 5.102 and 8.769 ppm, respectively. Also, the maximum contents of $\mathrm{Zn}$ in plant stems and leaves were recorded in 
Table(4): Phenolic compounds composition $(\mu \mathrm{g} / \mathrm{g})$ in ethanolic extract of Senniella spongiosa during winter and summer using HPLC.

\begin{tabular}{|l|c|c|}
\hline \multirow{2}{*}{ Phenolic compounds } & \multicolumn{2}{|c|}{$\begin{array}{c}\text { Phenolic compound } \\
\text { (Mg/g) }\end{array}$} \\
\cline { 2 - 3 } & Summer & Winter \\
\hline Resorcinol & 3.52 & 1.29 \\
\hline Protocatechuic acid & 7.92 & 4.87 \\
\hline$\rho$-hydroxy benzoic acid & 11.82 & 5.13 \\
\hline Pyrogallic acid & 0.32 & 0.08 \\
\hline Hydroqunion & 0.72 & - \\
\hline Gallic acid & 10.14 & 5.66 \\
\hline Chlorogenic acid & 15.21 & 7.11 \\
\hline Catechin & 4.72 & 2.17 \\
\hline Phenol & 14.40 & 7.34 \\
\hline Coumarin & 2.55 & 1.15 \\
\hline Myricetin & 2.36 & 1.18 \\
\hline Cinnamic acid & 0.34 & - \\
\hline Vanillin & 1.62 & 0.45 \\
\hline$\rho$-coumaric acid & 4.33 & 9.56 \\
\hline Ferulic acid & 17.24 & 6.19 \\
\hline Salicylic acid & 9.19 & 6.34 \\
\hline Rutin & 2.34 & 1.75 \\
\hline o-coumaric acid & 1.83 & 5.32 \\
\hline Quercetin & 0.42 & 0.22 \\
\hline Kaempferol & 2.25 & 0.51 \\
\hline
\end{tabular}

Table (5): Elements composition of the Senniella spongiosa stems and leaves.

\begin{tabular}{|c|c|c|c|c|}
\hline \multirow{2}{*}{$\begin{array}{c}\text { Element } \\
(\mathbf{p p m})\end{array}$} & \multicolumn{2}{|c|}{ Stems } & \multicolumn{2}{c|}{ Leaves } \\
\cline { 2 - 5 } & Summer & Winter & Summer & Winter \\
\hline $\mathrm{Al}$ & $<0.030$ & $<0.023$ & 5.909 & 4.532 \\
\hline $\mathrm{B}$ & 0.258 & 0.247 & 0.148 & 0.123 \\
\hline $\mathrm{Cd}$ & 0.003 & 0.002 & $<0.001$ & $<0.001$ \\
\hline $\mathrm{Co}$ & 0.111 & 0.001 & 0.039 & 0.013 \\
\hline $\mathrm{Cr}$ & 0.081 & 0.067 & 0.373 & 0.258 \\
\hline $\mathrm{Cu}$ & 1.181 & 1.099 & 0.852 & 0.654 \\
\hline $\mathrm{Fe}$ & 5.102 & 4.026 & 8.769 & 7.368 \\
\hline $\mathrm{Mn}$ & 0.198 & 0.176 & 0.463 & 0.197 \\
\hline $\mathrm{Mo}$ & $<0.004$ & $<0.003$ & $<0.004$ & $<0.002$ \\
\hline $\mathrm{Ni}$ & 0.062 & 0.042 & 0.069 & 0.051 \\
\hline $\mathrm{Pb}$ & 0.076 & 0.062 & 0.193 & 0.032 \\
\hline $\mathrm{Sr}$ & 1.256 & 1.104 & 2.827 & 2.347 \\
\hline $\mathrm{V}$ & $<0.007$ & $<0.004$ & 0.012 & 0.005 \\
\hline $\mathrm{Zn}$ & 5.316 & 4.012 & 5.922 & 4.562 \\
\hline $\mathrm{Na}$ & 72.13 & 64.51 & 789.63 & 739.50 \\
\hline $\mathrm{K}$ & 38.60 & 32.23 & 319.60 & 279.55 \\
\hline $\mathrm{P}$ & 2.73 & 3.56 & 12.88 & 16.60 \\
\hline $\mathrm{Ca}$ & 12.91 & 10.13 & 113.21 & 102.27 \\
\hline
\end{tabular}


summer (5.316 and $5.922 \mathrm{ppm}$, respectively).

Furthermore, the maximum content of $\mathrm{Na}^{+}$ in summer was $789.63 \mathrm{ppm}$ in plant leaves and the activation of its biosynthesis under osmotic stress have been investigated (Russell et al., 1998).

Table(6): Proline content and quaternary bases of the stems and leaves of Senniella spongiosa plant.

\begin{tabular}{|l|c|c|c|c|}
\hline \multirow{2}{*}{ Item } & \multicolumn{2}{c|}{ Stems } & \multicolumn{2}{c|}{ leaves } \\
\cline { 2 - 5 } & Summer & Winter & Summer & Winter \\
\hline Glycine betaine $\left(\mu\right.$ mole g $^{-1}$ d.wt.) & 1.02 & 0.34 & 1.90 & 0.63 \\
\hline Choline hydrochloride $\left(\mu\right.$ mole g $^{-1}$ f.wt. $)$ & 0.57 & 0.09 & 0.85 & 0.20 \\
\hline Proline $\left(\mu\right.$ mole ${ }^{-1}$ f.wt.) & 230.1 & 240.5 & 270.2 & 300.1 \\
\hline
\end{tabular}

d.wt. $=$ Dry weight

minimum value in winter was $64.51 \mathrm{ppm}$ in plant stem (Table 5). Maximum $\mathrm{K}^{+}$ion accumulation was achieved by plant leaves during summer (319.60 ppm), whereas the lowest cotent was observed in winter (32.23 ppm) in plant stems. Saltbushes, in general, are characterized by moderate crude protein and high mineral contents, particularly $\mathrm{Na}, \mathrm{K}, \mathrm{Cl}$ and $\mathrm{Ca}$ concentrations. Potassium is an important contributor to the osmotic potential of the cells while calcium is an important mineral for the construction of cell walls (Pessarakli, 1995). The reduction of phosphate concentration in stressed plants is due to its unavailability in the soil. Several studies have been conducted regarding the utilization of saltbushes in animal feeding (El Shaer et al., 1987).

\subsection{Proline content and quaternary bases}

Data presented in Table (6) show that the accumulation of proline in winter samples was 240.5 and $300.1 \mu$ mole $\mathrm{g}^{-1}$ f.wt. for plant stems and leaves, respectively, while glycine betaine and choline hydrochloride were higher in summer than in winter. High glycine betaine $(1.9 \mu$ mole $\mathrm{g}^{1}$.wt.) and choline hydrochloride $(0.85 \mu$ mole $\mathrm{g}^{1}$ d.f.wt.) contents were found in plant leaves during summer. The ability to accumulate proline has been used as a basis for selection for drought tolerance in several species (Strainer et al., 1995). Richard et al. (1979) reported that two Chenopodiaceae plants, Atriplex spongisa and Saueda monoica showed some fresh weight response to low salinity due to increased succulence. Both species had affinities for $\mathrm{Na}^{+}$and maintained constration but low shoot $\mathrm{K}^{+}$with increasing salinity. Also they reported that high glycine betaine contents were found in the shoots of both species and it is suggested that glycine betaine is the major cytoplasmic osmoticum (with $\mathrm{K}^{+}$salts) in these species at high salinities. Proline accumulation was observed in shoot tissues with suboptimal water contents. The importance of glycine betaine in osmotic adjustment and the

\section{REFERENCES}

Abo-Kassem E.M., Kasim W.A. and Hamada E.A.M. (2002). Effect of three potassium salts on some metabolites and enzyme activities in Raphanus sativus, L. seedlings. Proc. $2^{\text {nd }}$. Int. Conf. Biol. Sci., (ICBS) Fac. Sci., Tanta Univ., 409-420.

Aganga A. A., Mthetho J. K. and Tshwenyane S. (2003). Atriplex nummularia (Old man saltbush): A Potential Forage Crop for Arid Regions of Botswana. P. J. of Nutr., 2 (2): $72-75$.

Ahmed A.M. and Grigis W.A. (1979). Adaptive responses of plants of different ecological groups from Wadi Gharandal, Sinai, Egypt. Desert Inst. Bull.D.R.C.,29: 487-512.

Ahmed F. A. (2004). Chemical composition of Ballota undulata (Fresen.) Benth. (Family: Lamiaceae) growing naturally in north Sinai. Annals of Agric. Sci., Moshtohor, 42 (4): 1711-1731.

Ait Baraka E. and Audran J. C. (1997). Response of champenoise grapevine to low temperatures: Change of shoot and bud farinos concentrations in response to low temperatures and correlations with freezing tolerance. J. Hortic. Sci. Biotechnol., 72: 577-582.

Alabi D.A., Akinsulire O.R. and Sanyaolu M.A. (2005). Qualitative determination of chemical and nutritional composition of Parkia biglobosa (Jacq.) Benth. Afri. J. of Biotechnol., 4 (8): 812-815.

Allen S.E. (1989). Chemical Analysis of Ecological Materials. Oxford, Blackwell Scientific Puplications, 368 pp.

Al-Owaimer A. N., Zahran S. M. and Al-Bassam B. A. (2008). Effect of feeding some types of Atriplex spp. in complete diet on growth performance and digestibility of growing lambs. Res. Bult., No. (161), Food Sci. \& Agric. Res. Center, King Saud Univ., p.519. 
AOAC (2000). Official Methods of Analysis. (15 ${ }^{\text {th }}$ ed.). Association of Official Analytical Chemists, Inc., Washington D.C., USA.

Balbaa S.I. (1986). Chemistry of Crude Drug. Laboratory Manual Faculty of Pharmacy, Cairo University. 195 pp.

Ben-Hammouda M., Kremer R. J., Minor H.C. and Sarwar M. (1995). A chemical basis for differential allelopathic potential of Sorgum hybrids on wheat. J. Chem. Ecol., 21: 775786.

Bravo L. (1998). Polyphenolics: chemistry, dietary sources metabolism and nutrional significance. Nutr. Rev., 56: 317-333.

Chaplin M.F. and Kennedy J.F. (1994). Carbohydrates Analysis - A Practical Approach. Oxford University Press, Oxford, New York., Tokyo. $2^{\text {nd }}$ Ed, 324 pp.

Chung K.T., Wong T.Y., Huang Y.W. and Lin Y. (1998). Tannins and human health: a review. Cited; Review, Food Sci. Nurt. 38: 421-464.

Edeoga H., Okwu D. and Mbaebie B. (2005). Phytochemical constituents of some Nigerian medicinal plants. Afri. J. of Biotechnol., 4(7): 685-688.

Edeoga H.O., Omosun G. and Uche L.C. (2006). Chemical composition of Hyptis suaveolens and Ocimum gratissimum hybrids from Nigeria. Afri. J. of Biotechnol., 5 (10): 892895.

Elabsy K.M. (2006). Biochemical adjustment of Nitraria retusa Asch. and Arthrocnemum macrostachyum K.Koch. to saline habitats. M.Sc. Thesis., Bot. Dept. Fac. Sci., Tanta Univ., Egypt.

El- Lamey T. M. (2005). The Effect of Some Ecological Factors on the Chemical Compounds in Some Xerophytes for Enhancing Their Use. Ph.D. Thesis, Department of Biological and Physical Science, Institute of Environmental Studies and Research, Ain Shams Univ. 216 pp.

El Shaer E.M., Rammah A., Nasr A. and Bayoumi M.T. (1987). Nutritional quality of some grasses in North Sinai. Proceedings of the $2^{\text {nd }}$ Int. Conf. Desert Develo., January 2530, Cairo, Egypt.

Emam S. S. and Ahmed F. A. (2006). Acids content of Senniella spongiosa (F. Muell.) Aellen. Egyptian J. Desert Res., 56 (1): 107127.

Gallher R. N. (1975). The occurrence of calcium in plant tissue as crystals of calcium oxalate. Commun. Soil Sci. Plant Anal. 6315.

Gershenzon J. (1984). Changes in the Levels of Plant Secondary Metabolites Under Water and Nutrient Stress. In Phytochemical Adaptation to Stress, Recent Advances in Phytochemistry. Timmermann, B. N.; Stellink, C. and Loewus, F. A., (Eds.), Plenum Press, New York, p. 270-320.

Ghazanfar S. A. (1994). Hand Book of Arabian Medicinal Plants. CRC Press, Boca Raton, Ann Arbor, London. Tokyo. 120-127.

Hodgkinson A. (1971). Determination of oxalate in stones. J.Clin. Patho. 24,147.

Houerou H.N.K., Le Houerou H.N., Choukr Allah R., Malcolm C.V. and Hamdy A. (1995). Forage halophytes in the Mediterranean Basin. Halo. and Bio. Agri., 115-136.

Humphries E.C. (1956). Mineral Composition and Ash Analysis. In Modern Methods of Plant Analysis. (Peatch, K. and Tracey, M.V., Eds.) 1, 148, Springer, Verlage, Berlin.

Jain V.K. (1997). Fundamentals of Plant Physiology. $5^{\text {th }}$ Ed, Published by S. Chand Company Ltd., Ram Nagar, New Delhi. 137 pp.

Karaway M.S. and Aboutabl E.A. (1982). Phytoconstituents of Tabernaemontana cornaria Jac Q. Wild and Dichotoma Roxb growing in Egypt.Part IV: The flavonoids. Bull. of Fac. Pharm. Cairo Univ. XXI (1): 41-49.

Larcher W. (1995). Physiological Plant Ecology. Springer Verlage, Berlin Heidelberg, Germany. 506 pp.

Lever M., Bason L., Leaver C., Hayman C. M. and Chambers S. T. (1992). Same-day batch measurements of glycinebetaine, carnitine and other betaine in biological material. Anal. Biochem., 205: 14-21.

Mckell C.M. (1989). Shrub Biology and Utilization. Academic Press, New York, 556 pp.

Mckell C.M. (1994). Salinity tolerance in Atriplex species: Fodder shrubs of arid lands. In: Pessarakli P. ed. Handbook of Plant and Crop Stress. New York: Marcel Dekker, Inc., P. 497-503.

Metzner H., Rau H. and Senger H. (1965). Mntersuchungen Zur Synchrom isier beckeit einzellner-Pigment. Mangol Mutanten von Chloella. Planta, 65: 186.

Mohamed N. and Alain C. (1995). Effects of sodium chloride on growth, tissue elasticity and solute adjustment in two Acacia nilotica sub-species. Physiol. Plant., 93: 217-224.

Mojab F., Kamalinejad M., Ghaderi N. and Vahidipour H. (2003). Phytochemical screening of some species of Iranian plants. Iranian Journal of Pharmaceutical Research, 2:77-82. 
Morsy A.A. (2002). Ecophysiological Studies on Certain Wild Plants Grown In Different Habitats in the Egyptian Deserts. Ph. D. Thesis., Bot. Dept., Fac. Sci., Ain Shams Univ., Cairo, Egypt.

Morsy A.A. (2008). Ecophysiological studies on Atriplex farinosa Forssk. under different habitat conditions. Aust. J. of Basic and Applied Sci., 2(2): 272-281.

Oke O.L.(1966). Nutritive Values of Mushrooms. West Afr.Pharm., 8(3):51-54.

Pessarakli M. (1995). Hand Book of Plant and Plant Physiology. Library of Congress Catalloging in Publication Data. Printed in the USA, Marcel Dekker, Inc. New York, Basel, Hong Kong. 1004 pp.

Petterson D.S., Harris D.J., Rayner C.J., Blakeney A.B. and Choct M. (1999). Methods for the analysis of premium livestock grains. Aust. J. of Agric. Res., 50: 775-787.

Polterait O. (1997). Antioxidants and free-radical scavengers of Natural Origin. Current Org. Chem., 1: 415-440.

Pulido R., Bravo L. and Saura-Calixto F. (2000). Antioxidant activity of dietary polyphenols as determined by a modified ferric reducing/antioxidant power assay. J. Agric. Food Chem. 48: 3396-3402.

Ray Sahelian M.D. (2005). Apigenin inhibits VEGF and HIF-1 expression. Eur.J.Pharmacol. 11; 512 (2-3): 189-98.
Richard S., Jones R. and Gareth W. (1979). Responses of Atriplex spongiosa and Suaeda monoica to salinity. Plant Physiol., 63 (1): 156-162.

Rizk A.M. (1986). The Phytochemistry of the Flora of Qatar. Sci. App. Res. Cent. Qatar Univ., King Printed Ltd. London. p:361364.

Russell B. L., Rathinasabapathi B. and Hanson A. D. (1998). Osmotic stress includes expression of choline monoxygenase in sugar beet and amaranth. Plant Physiol., 116: 859-865.

Shani J., Ahronson Z. and Sulman F.G. (1972). Insulin-potentiating effect of saltbush (Atriplex halimus) ashes. Isr. J. Med. Sci., 8: 757-758.

Sofowara A. (1993). Medicinal Plants and Traditional Medicine in Africa. $2^{\text {nd }}$ Edn. Spectrum Books Ltd, Ibadan, Nigeria. 289 PP.

Strainer D., Minica Duckie N. and Gasic O. (1995). Adaptability to drought in sugar beet cultivars. Biologia Plantarum, 37:107112.

Van-Burden T.P. and Robinson W.C. (1981). Formation of complexes between protein and tannin acid. J. Agric. Food Chem. 1: 77.

Woo W.S., Chi H.J. and Yun H.S. (1977). Alkaloid screening of some Saudi Arabian Plants. Kor. J. Pharmacog., 8(3): 109-113.

$$
\begin{aligned}
& \text { Senniella spongiosa المكونات الكيميائية لنبات } \\
& \text { فاطمة على أحمد - ش شلبية شحات امـام } \\
& \text { قسم النباتات الطبية و العطرية ـ مركز بحوث الصحر اء ـ المطرية ـ القاهرة ـ مصر }
\end{aligned}
$$

ئهدف هذا البحث إلى دراسة التركيب الكيميائى لأوراق وسيقان نبات Senniella spongiosa المعمر تحت تاثير

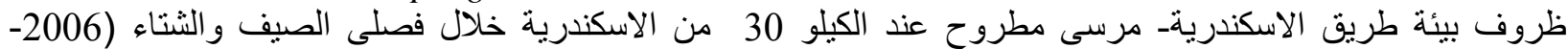

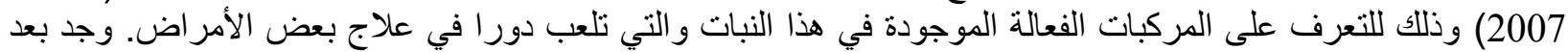

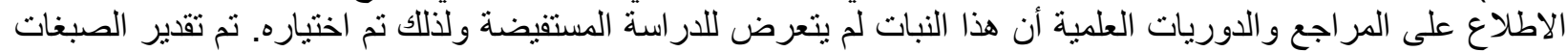

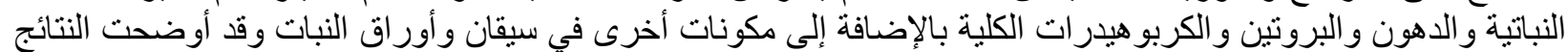

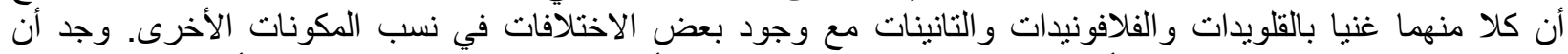

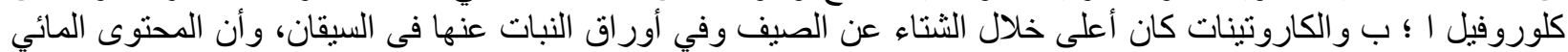

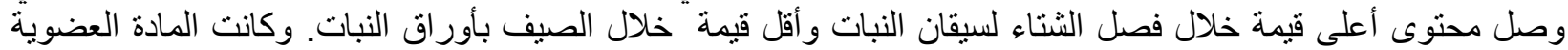

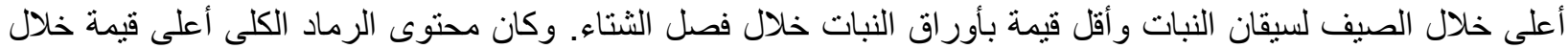

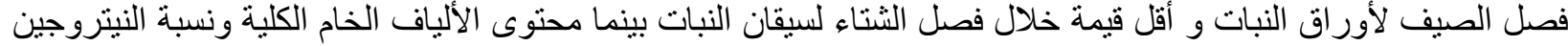

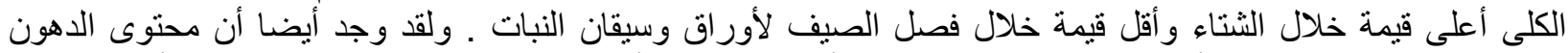

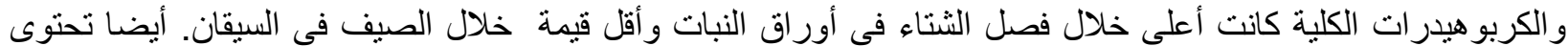

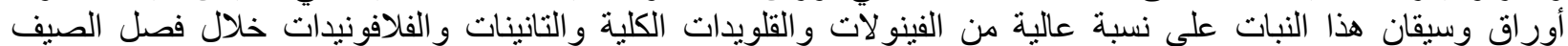




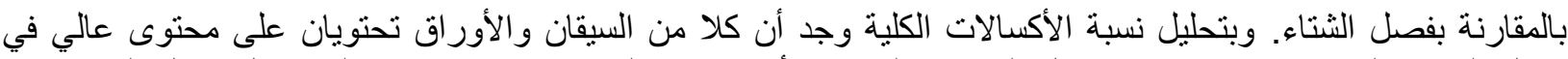

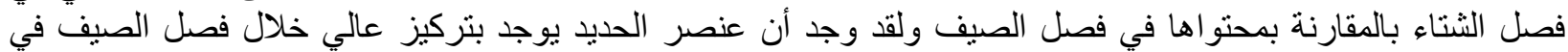

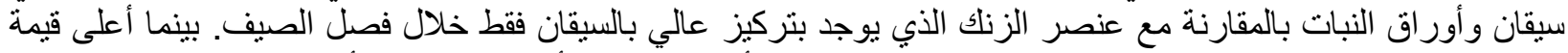

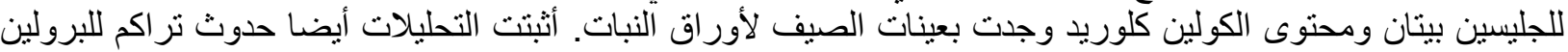

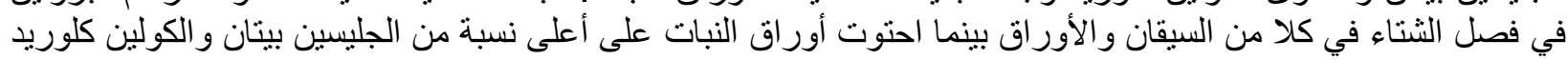
بالمقارنة بسيقان النبات.

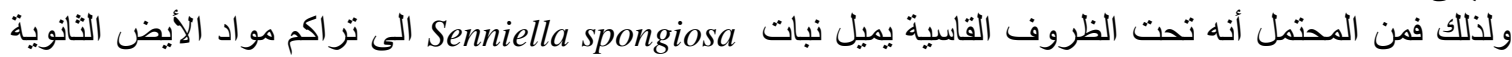
و التى ربما تكون عاملا هاما للتأقلم مع الظروف النيئية غير المناسبة لنمو النبات.

المجلة العلمية لكلية الزراعة ـ جامعة القاهرة ـ المجلد (60) العدد الرابع (اكتوبر 2009): 378-387. 